УДК : 327

\title{
ПОКАЗНИКИДОВІРИ НА РІВНІ МІЖДЕРЖАВНИХ ВІДНОСИН ЗА ПІДТРИМКИ КУЛЬТУРНОЇ ДИПЛОМАТІї
}

\section{Герман Анастасія Леонідівна}

генеральний директор ТОВ «Івент агенція Анастасії Герман», блогер,

м. Київ, Україна

ORSID: 0000-0001-9028-1915

herman.anastasiya@gmail.com
Надіслано:

09.02.2020

Рецензовано:

04.03.2020

Прийнято:

15.03.2020

Стаття присвячена виокремленню та аналізу основних показників довіри на рівні міждержавних відносин, акцентуючи увагу на ефективності культурної дипломатії у цих процесах. Це питання має теоретичну та практичну цінність: отримані результати можуть застосовуватися як для подальшої поглибленої теоретичної розробки проблем у міжнародних відносинах, так і в дипломатичній практиці, під час розвитку економічних і культурних зв'язків між народами, у процесі підготовки фахівців з державного управління, міжнародних відносин та ін.

Методологія дослідження в рамках запропонованої статті в основному базується на комплексному підході з використанням методології системнофункціонального аналізу, категоріального апарату політології, соціології, соціальної психології, теорії комунікацій, компаративістики та ін. гуманітарних дисциплін. Встановлено, що державна довіра відноситься до явищ, які містять долю ризику у взаємодії з ін. державами, допомагають вирішити різні колективні проблеми та діяти у спосіб, який суперечить стандартним визначенням національних інтересів. Виокремлено п'ять показників існуючої довіри у контексті міждержавних відносин: 1) мінімальний рівень - співпраця між державами; 2) нижній середній рівень - вигідна орієнтація політики держав; 3) середній рівень - проведення доброзичливої політики між державами; 4) верхній середній рівень - види письмових правил із часовим запасом; 5) високий рівень - дискреційна влада у процесі розробки політики. Виділено 9 показників ефективності культурної дипломатії під час побудови довіри на рівні міждержавних відносин: зміст культурної та зовнішньої політики;соціальні ролі, формальний договір та встановлені зобов'язання між державами;якість культурних дипломатичних програм;координація між різними урядовими відомствами та ін. установами в межах і між державами; існуюча недовіра та конфліктні питання між державами;зловживання 
фінансуванням культурних дипломатичних програм;функціонування закордонних культурних установ;публічність щодо програм культурної дипломатії;моніторинг впливу після культурно-дипломатичної діяльності.

Ключові слова: міждержавні відносини; довіра; показники державної довіри; культурна дипломатія; взаємна доброзичлива політика; співпраця.

German Anastasia, General Director of Event Agency Anastasia German LLC, blogger, Kyiv, Ukraine

\section{Trust Indexes on the Level of Inter-State Relations with the Support of Cultural Diplomacy}

The article is dedicated to the isolation and analysis of the main trust indexes on the level of the inter-state relations paying attention on the effectiveness of cultural diplomacy in these processes. This question has a theoretical and practical value: the received results can be used both for further deep theoretical problem development in international relations and in diplomatic practice due the economic and cultural connections development among nations, during the process of preparing specialists in state regulation, international relations, etc.

Methodology of the research is mostly based on the complex approach with using methodology of system-functional analysis, categorical apparatus of Politology, Sociology, Social Psychology, and Theory of Communication, Comparativistics and other Humanities. It is found that the state trust refers to such phenomena, which contain a part of risk in the cooperation with other states, help to solve different collective problems and act in the way, which contradicts the standard definitions of national interests. It is found five indicators of existing trust in the context of interstate relations: 1) minimal level - is cooperation among states; 2) lower level is favourable policy of states orientation; 3) middle level - is to conduct the friendly policy among the states; 4) upper level - is types of written rules with temporal storage; 5) high level - is discretionary power in the process of developing politics. It is highlighted 9 indexes of cultural diplomacy effectiveness due the trust building on the level of inter-state relations: content of cultural and Foreign policy; social roles; a formal agreement and obligations between the states; the quality of cultural diplomatic programs; coordination between different government departments and other agencies within and between states; existing mistrust and conflicting issues between states; misuse of funding for cultural diplomatic programs; operation of foreign cultural institutions; publicity about cultural diplomacy programs; impact monitoring after cultural and diplomatic activity.

Key words: inter-state relations; trust; indexes of state trust; cultural diplomacy; mutual friendly policy; cooperation. 
Міжнародні відносини: теоретико-практичні аспекти

Випуск 5 (2020)

ISSN (print) 2616-745X; ISSN (online) 2616-7794

Герман Анастасия Леонидовна, генеральный директор ООО «Ивент агентство Анастасии Герман», блогер, г. Киев, Украина

\section{Показатели доверия на уровне межгосударственных отношений при поддержке культурной дипломатии}

Статья посвящена определению и анализу основных показателей доверия на уровне межгосударственных отношений, акцентируя внимание на эффективности культурной дипломатии в этих процессах. Этот вопрос имеет теоретическую и практическую ценность: полученные результаты могут применяться как для дальнейшей углубленной теоретической разработки проблем в международных отношениях, так и в дипломатической практике, при развитии экономических и культурных связей между народами, в процессе подготовки специалистов по государственному управлению, международным отношениям и др.

Методология исследования в рамках предлагаемой статьи в основном базируется на комплексном подходе с использованием методологии системнофункционального анализа, категориального аппарата политологии, социологии, социальной психологии, теории коммуникаций, компаративистики и других гуманитарных дисциплин. Установлено, что государственное доверие относится к явлениям, которые содержат долю риска во время взаимодействия с другими государствами, помогают решить различные коллективные проблемы и действовать таком образом, что это не противоречит стандартным определением национальных интересов. Выделены пять показателей существующей доверия в контексте межгосударственных отношений: 1) минимальный уровень - сотрудничество между государствами; 2) нижний средний уровень - выгодная ориентация политики государств; 3) средний уровень - проведение доброжелательной политики между государствами; 4) верхний средний уровень - виды письменных правил с временным запасом; 5) высокий уровеньдискреционная власть в процессе разработки политики. Указано 9 показателей эффективности культурной дипломатии при построении доверия на уровне межгосударственных отношений: содержание культурной и внешней политики; социальные роли, формальный договор и установленные обязательства между государствами; качество культурных дипломатических программ; координация между различными правительственными ведомствами и другими учреждениями в пределах и между государствами; существующее недоверие и конфликтные вопросы между государствами; злоупотребление финансированием культурных дипломатических программ; функционирование иностранных культурных учреждений; публичность касательно программ культурной дипломатии; мониторинг влияния после культурно-дипломатической деятельности. 
Ключевые слова: межгосударственные отношения; доверие, показатели государственного доверия; культурная дипломатия; взаимная доброжелательная политика; сотрудничество.

\section{Вступ}

Вимірювання ефективності $\epsilon$ важливим аспектом пояснення інструменту культурної дипломатії та їі ролі у процесі зміцнення довіри з боку держави. При цьому, відсутність стандартизованих методів вимірювання залишається сьогодні великою проблемою. Приміром, з огляду на велику кількість культурних дипломатичних програм неможливо виміряти всі результати однаковими інструментами. Крім того, через суттєву різницю цілей, підходів, методологій культурних дипломатичних програм та їх оцінок значна частина отриманих оціночних даних не співставна.

Нині майже не існує дієвих методів вимірювання ефективності культурної дипломатії у розбудові довіри на рівні міждержавних відносин, інших відповідних нематеріальних ефектів, які можна було б виміряти за допомогою показників й факторів, які потенційно можуть бути використані для демонстрації довірчих відносин між державами, створених засобами культурної дипломатії. Довіра базується на сприйнятті, і її вимірювання часто пов'язане 3 багатьма проблемами, що теж $\epsilon$ важливим моментом для культурної дипломатії.

Соціологами були вироблені деякі стандарти вимірювання оцінки довіри. Наприклад, А. Гоффман запропонував три правила для визначення довіри: 1) політика дискреції (власного розсуду) та дані прийняття рішень; 2) індикатори нагляду; 3) показники правил. Однак вчений не погоджується, що співпраця може використовуватися як один із показників вимірювання довіри. Він стверджує, що «сам (Hoffman, 2002, p. 376).а наявність співпраці є ненадійним показником довіри» Інші вчені (Coleman, 1990; Deutsch, 1958; Gambetta, 1988; Larson, 1998) твердять, що стратегії вимірювання, засновані на прогностичних визначеннях довіри, припускають, що вона $\epsilon$ необхідною умовою співпраці.

Хоч А. Гоффман розглядає довіру між державами, проте це не те саме, що поняття державної довіри. Ця теза виражає суть двох правил вимірювання методології А. Гоффмана: по-перше, це дослідження узгоджується з важливістю розсуду у рамках політики; по-друге, це дослідження використовує показники норм, щоб дослідити існування довіри держави. Що стосується відносин між культурною дипломатією та державною довірою, то подібне дослідження також пропонує три такі показники: 1) взаємна доброзичлива політика; 2) вигідна орієнтація політики та 3) співпраця. 
Міжнародні відносини: теоретико-практичні аспекти

Випуск 5 (2020)

ISSN (print) 2616-745X; ISSN (online) 2616-7794

\section{Аналіз останніх досліджень і публікацій}

Наукове осмислення, політологічний аналіз проблеми довіри як засобу оптимізації міжнародних відносин відстає від потреб політичної практики. Роботи, спеціально присвячені цій тематиці, починають з'являтися від 1975 р., з часів Гельсінкської наради і, як правило, стосуються військово-політичних аспектів довіри. I лише на початку 2000-х рр. ця проблематика стає предметом міждисциплінарного розгляду, об'єднуючи навколо себе зусилля економістів, політологів, філософів, соціологів та ін. групи дослідників. Цікавою видається спроба розглянути проблему довірчих відносин на міждержавному рівні крізь призму ефективності залучення культурної дипломатії до цих процесів. У цьому ключі цікавими є роботи зарубіжних дослідників (Baier, 1986; Barton, 2016; Coleman, 1988; Deutsch, 1977; Durden, 2017; Gambetta, 1988; Hoffman, 2002; Kang, 2015; Larson, 1997).

\section{Виділення невирішених раніше частин загальної проблеми}

Поза увагою дослідників, враховуючи окреслений контекст проблеми, залишається питання індикаторів наявної державної довіри за сприяння культурної дипломатії та виокремлення факторів, які можуть впливати на ефективність останньої.

\section{Формулювання мети і завдань статті}

Метою дослідження, результати якого презентовані у цій статті,є спроба виокремлення та узагальнення основних показників існуючої довіри у контексті міждержавних відносин, під час забезпечення якої важливу роль відіграють інструменти культурної дипломатії. Задля досягнення поставленої дослідницької мети визнано за необхідне з'ясування змісту поняття «державна довіра»; чітке формулювання її показників на рівні міждержавних відносин; характеристика цих показників; виокремлення ознак ефективності культурної дипломатії у межах державного довірчого будівництва.

\section{Виклад основного матеріалу дослідження}

Перший показник - співпраця між державами - вказує на мінімальний рівень державної довіри.

Культурна дипломатія може створити можливості для співпраці. Однак, як перетворити ці можливості на конкретні практичні дії, а не залишатися на рівні усної обіцянки. Багато вчених погоджуються, що довіра $\epsilon$ необхідною умовою співпраці (Coleman, 1990; Deutsch, 1958; Gambetta, 1988; Larson, 1998). Суверенна держава не є винятком. Держави, які передають певний контроль над своїми інтересами іншим державам, ризикують зрадити ці інтереси. Уся співпраця вимагає певної міри довіри. Коли держави мають все більше спільних досягнень, то між ними існує певний ступінь довіри, навіть якщо остання перебуває на мінімальному рівні. 
А.Гоффман не згоден 3 таким підходом, вважаючи, що «довіра передбачає ризик, але не може бути зведена до ризику - довіра та ризик $\epsilon$ роздільними конструкціями. Мається на увазі, що необхідний зв'язок між довірою та співпрацею не може бути стійким через те, що деякі зусилля до співпраці не виникають 3 тієї причини,що i бажання гравців грати, заручившись несприятливими або навіть поганими шансами» (Hoffman, 2002, p. 400). Він пропонує американо-радянські ядерні відносини як приклад для пояснення кооперативного ризику без довіри. А.Гоффман стверджує, що використання наддержавами високоінвазивних й регулярних перевірок запасів ядерної зброї одна у одної, навряд чи свідчить про довірливі та партнерські відносини.

Аргумент А. Гоффмана певною мірою обгрунтований, але, насамперед, у реальному політичному світі немає абсолютної довіри. Тому неможливо або практично неможливо вимагати 100 \% довіри від держав у рамках співпраці. Як зазначає Бартон, «співпраця має значення не лише як шлях подолання політичного розриву, прагнучи уникнути несприятливих наслідків конкурентної поведінки,але також $\epsilon$ актуальною, позаяк обидві сторони зацікавлені у взаємній допомозі одна одній» (Barton, 2016, p. 41).

Деякі вчені використовують «дилему в'язня» (Prisoner's dilemma) для пояснення міжнародного співробітництва між державами: гра з ненульовою сумою, в якій гравці прагнуть одержати вигоду, співпрацюючи один з одним або зраджуючи. Видно чітко, що співробітництво між державами в структурі дилеми ув'язнених вимагає, щоб обидві сторони довіряли одна одній, щоб реалізовувати спільні процедури та максимізувати вигоду. Більше того, концепція довіри держави $є$ похідною від концепції соціальної довіри, де одним із ключових $є$ поняття взаємності. Співпраця - один із декількох способів взаємності.

Наприклад, якщо держава А вирішить співпрацювати з державою Б на базі спільної дії, породженою культурною дипломатією; за цієї обставини держава А повинна ставитися до держави Б як до партнера. Якщо обидві держави зберігають довіру без зради партнерства, тоді вони матимуть можливість реалізувати взаємну вигоду. Якщо обидві держави не зраджують, але все ж не змогли отримати жодної вигоди від співпраці, це не обов'язково $є$ проблемою довіри, але може бути наслідком деяких помилкових рішень.

Крім того, значні спільні досягнення не обов'язково представляють вищий рівень державної довіри, оскільки не усунуто питання, які можуть бути пов'язані 3 проблемою вигоди чи інтересу. 3 іншого боку, більш високі результати співпраці можуть підтримувати рівень довіри та забезпечувати для обох держав кращі можливості розвитку в майбутньому. Обидві держави 
можуть надалі зміцнювати та поглиблювати взаєморозуміння на платформі співпраці.

Другий показник - взаємна доброзичлива міждержавна політика - може свідчити про більш низький середній рівень довіри з боку держав.

За визначенням, взаємна доброзичлива політика - це державна політика зі сприятливим i корисним змістом. Наприклад,уряд Великобританії, ініціювавши план виходу з Європейського Союзу,висунув серію доброзичливих політичних пропозицій до китайського уряду, які б в подальшому зміцнили економічні та культурні відносини між країнами (Department of International Trade, 2016). У відповідь Китай активно відреагував на пропозиції уряду Великобританії та почав заохочувати власні підприємства інвестувати у Великобританію. По-перше, можливо, що обидва уряди усвідомили вигоду,яку можна отримати за рахунок розвитку безпрограшної ситуації, що цілком відповідає національним інтересам; а по-друге, 2015 р. як культурний рік між країнами лише зміцнив взаєморозуміння між ними. Вищезгадане є не лише показником національного інтересу, але, мабуть, також і питанням довіри держав. Уряд Великобританії твердо вірить, що інвестиції 3 Китаю виправдають себе, і що можна прогнозувати майбутні результати інвестицій.

Однак доброзичлива політика тут є взаємною угодою, яка потребує зусиль суб'єктів обох держав для їі розробки та реалізації. Якщо один із державних суб'єктів відмовляється проводити доброзичливу політику, це не доводить, що між ними немає довіри, але можна припустити, що рівень їх довіри відносно низький. Наприклад, якщо держава А довіряє державі Б, то вона проводить доброзичливу політику щодо неї, але це не буде свідчити про середній рівень довіри, якщо держава Б також не буде виконувати аналогічну роботу стосовно держави А або, принаймні, позитивно відповідатиме на пропозиції. Державна довіра наголошує на взаємності між державами, тому вони докладають чимало зусиль у культурній дипломатії, реалізуючи курс доброзичливої політики.

Третій показник - сприятлива орієнтація політики - вказує на середній рівень довіри держави.

На відміну від другого індикатора, який в основному зосереджений на доброзичливому змісті політики, слово «орієнтація» в цьому випадку стосується сприятливої чи несприятливої тенденції. Подібна орієнтація означає, що впродовж відносно тривалого періоду державні суб’єкти реалізують низку урядових стратегій, програмних заяв й доповідей комітетів, які виражають волю відповідних урядів. Сприятливу тенденцію можна також назвати перспективною тенденцією,яка означає тенденцію все більш доброзичливої політики протягом тривалого періоду. Що стосується несприятливої тенденції, то на відміну від сприятливої, державні суб’єкти 
проводять усе більш ворожу політику відносно один одного. Несприятливість ситуації ще не свідчить про відсутність довіри між державами, але, швидше за все, завдає шкоди їхнім довірчим відносинам.

Інша точка зору свідчить про те, що сприятливу орієнтацію політики також можна трактувати як спосіб створення довіри, а не як показник існуючого їі рівня. Без сумніву, коли держава А постійно проводить вигідну політику щодо держави Б, така поведінка може розглядатися як зусилля держави А встановити довірливі відносини. У цій ситуації вигідна політика держави А розглядається як спосіб демонстрації своєї доброї волі чи доброзичливого ставлення до держави Б з метою таких відносин. Проте, подібна спрямованість політики не тотожна єдиному їі вектору чи курсу. Цей нижчий середній рівень довіри державне може розглядатися лише як прийняття та реалізація однієї конкретної політики, адже для її демонстрації потрібен відносно тривалий період. Щоразу, коли держава приймає та проводить невигідну політику, як результат, інша держава може не відповісти взаємністю, відповідно, державну довіру буде складно налагодити. Ось чому орієнтація політики зі сприятливою тенденцією може розглядатися як індикатор середнього рівня державної довіри.

Четвертий показник - загальні письмові правила з обмеженим терміном дії - свідчить про верхній середній рівень державної довіри.

Йдеться про такі правила як спільна заява чи договори, які, як правило, представлені у письмовій формі і не є лише усними обіцянками. Такі взаємні домовленості виникають тоді, коли обидві держави докладають зусиль для досягнення консенсусу, щоб надати один одному ступінь свободи дій у межах узгоджених правил. А. Гоффман стверджує, що «різні види правил забезпечують акторів різною мірою свободи прийняття рішень. За умови рівності, правила, які надають акторам найбільше свободи, вказують на довірливі стосунки» (Hoffman, 2002, p. 380). Цей показник можна проілюструвати спільними заявами держав, наприклад, заявою уряду КНР і уряду Сполученого Королівства Великобританії та Північної Ірландії, а також апеляцією до вже згаданого 2015-го як культурного року між країнами.

Деякі вчені стверджують, що письмові угоди вважаються сигналом про те, що партнери $з$ підозрою ставляться один до одного (Baier, 1986). Вони припускають, що немає необхідності у публікації такої письмової заяви, якщо між державами справді партнерські та взаємонадійні відносини. Ще один аргумент полягає в тому, що ситуація, коли державні суб'єкти погоджуються 3 вигідними або взаємними правилами,в основному залежить від відповідних національних інтересів, тобто вони укладають угоди, оскільки вважають, що цільова держава може принести їм значну економічну чи військову вигоду. Тому це не $є$ показником щирої довіри між державами. 
Наявність письмового документа може допомогти уникнути ризиків. По-перше, якщо заяви публічно оприлюднюються, більшість держав, ймовірно, не наражають на ризик національний імідж та репутацію. Зрештою, держави не можуть поводитися таким чином, щоб змінювати свої політичні та дипломатичні поглядів без будь-яких конкретних причин. По-друге, письмові угоди забезпечують державних суб’єктів інструментом реалізації. Загалом, ті, хто відповідає за виконання угод, як правило, не є тими самими особами, які уклали початкові угоди або контракти. У цьому випадку письмові угоди та домовленості є важливими інструментами, що дозволяють передавати права та обов'язки тим особам, які зобов'язані їх виконувати. По-третє, письмові угоди можуть виступати в якості опори для державних суб'єктів, коли відбуваються несподівані зміни, наприклад, кадрові перестановки. На організаційному рівні, щоб бути захищеними від кадрових змін, потрібні письмові угоди для майбутніх посадових осіб, які можна використати в якості довідникового матеріалу після того, як основні учасники переговорів полишать свої посади (Hoffman, 2002, p. 390).

Стосовно питання порушення правил та зменшення потенційних ризиків, то можна застосувати два види угод. А. Гоффман визначає їх як: 1)рамкові угоди, в яких переважають конституційні норми, котрі визначають основну структуру, інституціональні форми, процедури та право, а ці «конституційні правила» створюють та регламентують законну поведінку сторін; 2)статутно-орієнтовані угоди, де переважають конкретні кодекси, що регулюють поведінку суб'єктів за певних обставин (Hoffman, 2002, p. 391).

На рахунок дискреційного варіанта та можливої свободи дій, рамковоорієнтовані угоди можуть запропонувати державним суб'єктам деяку додаткову широту порівняно з угодами, орієнтованими на законодавство, оскільки правила, від яких залежить визначення способів взаємодії, розробляються без визначених часових меж. Навпаки, угоди, орієнтовані на законодавство, схожі на регуляторні норми, які створюють конкретні заборони поведінки, регулюючи не лише те, як повинні поводитися державні суб'єкти, а й те, коли певну поведінку слід здійснювати (або уникати). Рамкові угоди, як правило, більше узгоджуються з довірчими стосунками, ніж угоди, орієнтовані на статут. Однак, якщо державні суб'єкти повинні обирати угоди, орієнтовані на статут, цей вибір не означає, що між ними не існує державної довіри. Прикладом такого типу рамково-орієнтованої угоди зі свободою дій є Угода про взаємну оборону між США та Республікою Корея.

Інший можливий аргумент, який тут варто згадати, полягає в тому, чи існує державна довіра, коли ще не розроблені жодні типи правил. Це рідкість у сучасному міжнародному товаристві. Більшість держав мають політичні та дипломатичні зв'язки, при цьому деякі з них можуть ніколи не випускати 
спільної заяви. Використання лише одного показника, щоб оцінити існування державної довіри, може вважатися необ'єктивним. Можливо, саме цей показник здатен довести, що рівень довіри не зовсім досяг верхнього середнього рівня, але інші показники можуть мати здатність демонструвати існування цієї довіри.

Більше того, стосовно взаємозв'язку культурної дипломатії та державної довіри не важко зрозуміти суть:коли держава ініціює програми культурної дипломатії відносно іншої держави або обидві погодилися проводити культурну дипломатію разом, звичайно зрозумілою $є$ публікація офіційної заяви на державному рівні, хоча $є$ й інші способи оголосити домовленості без письмового документа. Ці правила, таким чином, нагадують обом державам про необхідність поводитися так, як визначено в офіційній заяві. Наприклад, коли держава А і держава Б приділяють великі зусилля культурній дипломатії одна одної, то вони зазвичай публікують спільну заяву чи інші правила з легкістю. Крім того, зміст цього висловлювання зосереджується, насамперед, на загальних цілях, спільних зусиллях щодо вдосконалення, а також іншій позитивній інформації, а не лише на вимогах чи обмеженнях. За цих умов можна стверджувати, що верхній середній рівень довіри існує між державою А та державою Б.

П’ятий показник - дискреції у розробці політики та ї̈ реалізації це показник державної довіри на високому рівні.

На політичній арені політику можна розглядати як невербальну волю держави, а також керівництво 3 прийняття рішень для урядів та держав, з метою досягнення бажаних результатів. Під час оцінки ефективності культурної дипломатії у зміцненні державної довіри неможливо нехтувати культурною політикою та пов'язаною 3 нею політикою зовнішньою; це особливо важливо у процесі розробки та реалізації політики. Через те, що культурна політика та пов'язана із нею зовнішня політика є найважливішими аспектами культурної дипломатії, і їі можна розглядати як потенційного будівничого державної довіри, то важливо усвідомити, що між політикою та державною довірою існує міцний зв'язок. Більше того, способи вироблення та реалізації політики, особливо коли вони пов'язані 3 дискреційними повноваженнями,вважаються вагомим фактором під час вивчення державної довіри.

Дискреція - термін, який часто використовується в галузі економіки, фінансів та права; вона рідко згадується на політичній арені,за винятком сфери державного управління. Наприклад, у макроекономіці дискреційна політика $є$ економічним інструментом, заснованим на судженнях політиків, на відміну від тієї політики, де все відбувається за заздалегідь визначеними правилами. Наприклад, центральний банк може приймати рішення щодо процентних 
ставок у кожному конкретному випадку замість того, щоб дозволяти встановленому правилу визначати процентні ставки або грошову масу.

У політиці термін «дискреція» має більше значення щодо громадської адміністрація або державного управління, надає їм специфічну сферу прийняття рішень. А. Гоффман висуває свою думку щодо дискреції та довіри, «довірчі міждержавні відносини виникають тоді, коли лідери вважають, що їхні колеги є надійними i, виходячи 3 цього сприйняття, приймають політику, яка робить їхні держави вразливими до дії своїх колег» (Hoffman, 2002, p. 376). Він вважає, що ці відносини з'являються тоді, коли актори віддають долю своїх інтересів на розсуд інших, сподіваючись, що ті будуть дотримуватися свого зобов'язання не використовувати свій розсуд, щоб їм нашкодити. Відповідно до такої позиції, це визначення передбачає, що вимірювання довірчих відносин передбачає дві важливі частини: 1) ідентифікація політики, яка надає іншим державам свободу дій щодо результатів, які раніше контролювалися першою державою;2) демонстрація того, що лідери хоча б частково, але відповідальні за прийняття такої політики,тому що вони вважали, що їхні колеги заслуговують на довіру (Hoffman, 2002, pp. 376-377).

Оцінюючи ефективність культурної дипломатії в державному довірчому будівництві, важливо виокремити дев'ять показників, які можна вважати своєрідним вимірювальним стандартом: а) певний зміст культурної політики та зовнішньої політики; б) чітко визначені соціальні ролі, формальний договір та встановлені зобов'язання між державами; в) якість культурних дипломатичних програм; г) координація між різними урядовими відомствами та іншими установами в межах та між державами; г); існуючі недовіри та конфліктні питання між державами; д) зловживання фінансуванням культурних дипломатичних програм; є) функціонування закордонних культурних установ; е) публічність щодо програм культурної дипломатії; ж) моніторинг впливу після культурно-дипломатичної діяльності.

\section{Висновки}

Таким чином, культурна дипломатія - динамічний і складний процес, що вимагає постійних зусиль, і це ж саме стосується побудови державної довіри. Довгостроковий вплив культурної дипломатії на формування довіри у міждержавних відносинах потребує багато років, оскільки пов'язані з цим результати та наслідки за часту носять нематеріальний характер. Державна довіра насправді відноситься до цілого ряду явищ, які дозволяють волевиявленню держав ризикувати у взаємодії 3 іншими державами,вирішувати проблеми колективних дій або діяти способами, які суперечать стандартним визначенням національних інтересів. У процесі доведення існування довіри з боку держав за підтримки культурної дипломатії, враховуючи поведінкові аспекти довірчих відносин, слід звернути увагу 
на п'ять показників існуючої довіри у контексті міждержавних відносин: 1) мінімальний рівень - співпраця між державами; 2) нижній середній рівень вигідна орієнтація політики держав; 3) середній рівень - проведення доброзичливої політики між державами; 4) верхній середній рівень - види письмових правил із часовим запасом; 5) високий рівень - дискреційна влада у процесі розробки політики.

Дуже часто лідери держав відіграють значну роль у подібних довірчих відносинах, оскільки це передбачає поєднання уявлень лідерів 3 їх вибором політики. Керівники держав зазвичай представляють ставлення та прагнення своїх країн, проте важливо розуміти, що дискреційна влада не обмежується привілеєм державних лідерів, а також може бути використана як прихильність або послуга між державами, які знаходяться у довірчих відносинах. Хоча дискреція не $\epsilon$ обов'язковою, проте вважається необхідною тому, що не важливо, наскільки точно розроблена політика, завжди виникають непередбачені обставини, що може призвести до несправедливих результатів, які потребують подальшого розгляду. Тому серед перспектив подальшого розгляду у межах цієї проблеми є аналіз зв'язку політики та дискреційної влади з двох точок зору, щоб надалі продемонструвати наявність державної довіри: по-перше, дискреційна влада у процесі розробки політики; по-друге, дискреційна влада з бездіяльністю під час реалізації політики.

\section{References:}

1. Baier, A. (1986). Trust and Antitrust. Ethics, issue 96(2), pp. 231-260.

2. Barton, B. (2016).Trust and the Politics of Security Risk Management The European Union's Engagement of China in Africa. King's College London.

3. Coleman, J. S. (1988). Social Capital in the Creation of Human Capital James S. Coleman. American Journal of Sociology, issue 94, pp. 94-120.

4. Deutsch, M. (1977). The Resolution of Conflict: Constructive and Destructive Processes. First Edit. Yale: Yale University Press.

5. Department for International Trade. (2016). A Guide for British Businesses Interested in Selling Goods and Services in China. The UK Government, [online]. Available at: https://www.gov.uk/guidance/exporting-to-china.

6. Durden, T. (2017). US Deploys Two More Aircraft Carriers Toward Korean Peninsula. Zerohedge.

7. Gambetta, D. (1988). Trust: Making and Breaking Cooperative Relations. Oxford: B. Blackwell.

8. Hoffman, A. M. (2002). A Conceptualization of Trust in International Relations. European Journal of International Relations, issue 8(3), pp. 375-401. 
Міжнародні відносини: теоретико-практичні аспекти

Випуск 5 (2020)

ISSN (print) 2616-745X; ISSN (online) 2616-7794

9. Kang, H. (2015). Contemporary cultural diplomacy in South Korea: explicit and implicit approaches. International Journal of Cultural Policy, issue 21(4), pp. 433447.

10. Larson, D. W. (1997). Trust and Missed Opportunities in International Relations. Political Psychology, issue 18(3), pp. 701-734.

11. US Department of State. (1954). U.S. Relations With the Republic of Korea. US Department of State, [online]. Available at: https://assets.documentcloud.org/documents/2830333/1954-U-S-ROK-MutualDefense-Treaty.pdf.

12. Stewart, P, Ali, I. (2017). U.S. Forges Ahead with South Korea Missile Defenses, Despite Upheaval. Reuters, [online]. Available at: http://www.reuters.com/article/us-southkorea-politics-usa-thaad-idUSKBN16H29S.

(C) Герман А. Л., 2020 